\title{
THE METROPOLISATION PROCESSES: A CASE OF CENTRAL EUROPE AND THE CZECH REPUBLIC
}

\author{
Milan Viturka, Vilém Pařil, Petr Tonev, Petr Šašinka, Josef Kunc*
}

\begin{abstract}
The article deals with the strategically important problems of metropolisation. In this context, it presents a theoretically based method of assessment of metropolises, the explanatory power of which was verified on the example of the Central Europe. This method is based on three components: population size (initial assumption), economic profile (ties to economic performance) and general attractiveness (the perception of development potential). The results of the evaluation of the 27 identified metropolises were generalized using a typology of their inclusion within the framework of the listed components: most metropolises were classified as type $B$ - an established metropolis, followed by type $C$ - an elementary metropolis, and type $A$ - a dominant metropolis. A practically targeted conceptualization is then demonstrated on the example of the Czech Republic. The main attention was focused on the intensity of the economic links of Prague (and two further Czech centres) with other Central European metropolises.
\end{abstract}

Keywords: metropolitan area, population size, economic profile, attractiveness, integration JEL Classification: O18, R11, R12, R58

\section{Introduction}

Metropolisation is one of the main symbols of long-term changes in the scale and form of urbanization happening in the background of the globalization process (Hanssens et al., 2012). In general, it is seen as a higher stage of urbanization, which is no longer primarily about the concentration of the population, but about the concentration of importance in the line of information-knowledge-management. This development supports the strengthening of the links

* Milan Viturka, Faculty of Economics and Public Administration, Masaryk University, Brno, Czech Republic (viturka@econ.muni.cz);

Vilém Pařil, Faculty of Economics and Public Administration, Masaryk University, Brno, Czech Republic (vilem@mail.muni.cz);

Petr Tonev, Faculty of Economics and Public Administration, Masaryk University, Brno, Czech

Republic (tonev@econ.muni.cz);

Petr Šašinka, Faculty of Economics and Public Administration, Masaryk University, Brno, Czech

Republic(206708@mail.muni.cz);

Josef Kunc, Faculty of Economics and Public Administration, Masaryk University, Brno, Czech

Republic (kunc@econ.muni.cz).

This work was supported by the Grant Agency of the Masaryk University under Grant

Metropolisation Processes Forming Traditional Structure of the City: An Example of Brno

Metropolitan Area (MUNI/A/0976/2016) and Czech Science Foundation under Grant "Spatial

Uncertainty and Fuzzy Regional Systems: Identification, Analysis and Implications of Pulsating

Functional Regions" (No. 16-13502S). 
between metropolises and their surroundings, and between metropolises with each other (Hampl, 1996). The increasing importance of the metropolises for the global competitiveness of countries stimulates the demand for theoretical and applied research of the issues.

The main objective of the article is to create comprehensive methods in order to evaluate a metropolis. Central Europe was chosen to verify the possibilities and the benefits of the applications of these (with an emphasis on the availability of the necessary information and a comparison of the results) and the Czech Republic was chosen for the practically oriented conceptualization of the research results, including the assessment of the potential cooperation and policy recommendation. Overall, however, it is necessary to say that there is still no consensus on the scientific definition of the metropolisation concept (Abrantes et al., 2005).

\section{Theoretical and Methodological Bases}

The basic leitmotiv of the further presented approach to the assessment of metropolisation processes is their understanding from the perspective of the post-industrial loosening of the horizontal forms of social organisation, and the deepening of vertical forms of this organisation. The position of the metropolis corresponds with the mentioned information as being an ever more dominant part of the national and supranational urban systems integrated not only by operational interactions mediated by the technical, in particular transport infrastructure (Kraft et al., 2014), but also the creative interactions mediated by the knowledge infrastructure. In this context, it is a characteristic development from the monocentric metropolitan agglomerations to polycentric macrosystems whose manifestation is creating supranational axes (Growe, 2012). The described development leads to significant changes in the localization of production - in this context, we can talk about a renaissance of localization approaches (Brender, Golden, 2007).

Using methodical approach to the assessment of the metropolisation process takes into account the knowledge of a series of theories of regional development. In addition to the theory of localization, there are e.g. the theories of central places, of polarized development and of cumulative causality, a deeper analysis of which goes beyond the thematic focus of the paper (for more details see e.g. McCann, 2010). In this respect, we consider the utilization of the working theory of integrated and sustainable regional development to be beneficial. This theory (Viturka, 2014) stresses, that the essence of the social movement is the hierarchical differentiation of social systems and their integration through the territorial division of labour and socio-political links. The resulting arrangement ensures the coherence of the systems, which reflects the balance between the effects of the economic, social and environmental factors, whose results are then accumulated in the quality of the business and social environment. ${ }^{1}$ The following decisive driving forces of integration are then considered: labour interactions on a microregional level, production interactions on a mesoregional level, administrative interactions on a macroregional level and trade interactions on a global level. Improvement in the quality of the business and social environments stimulates the development of different activities, with positive impacts on the creation of innovation and living standards.

1 Good informative ability of this theory is confirmed by the statistically verified hypotheses about the strong dependency between the business environment quality and the levels of GDP and population sizes of the regions. 
At the end of this section, selected issues related to the metropolisation are mentioned. In particular, it is an interesting fact that advances in ICT, overall, do not result in the dis-persion of information activities (see e.g. Sassen, 1991). This fact can be attributed to the need for face-to-face interactions, which is somewhat unequivocally referred to as the "tyranny of proximity" (Duranton, 1999; Bourdeau-Lepage, 2004). A controversial issue is the suburbanization, whose negative impacts are often interpreted in connection with the concept of urban sprawl (European Environment Agency, 2006). On the other hand, it is clear that suburbanization is an important tool for reducing the differences in the quality of the business environment between the core and hinterland. It is necessary to mention the local issues with potentially significant impacts on the overall attractiveness of cities, such as brownfields regeneration (see e.g. Frantál et al., 2015). The crucial question is then the management of metropolitan regions where the need for solutions to multiscale problems requires the application of integrative management (Ianos et al., 2012).

The mentioned theoretical ambiguity of the metropolisation concept complicates the evaluation of the metropolis position, starting with the definition itself. A systematic method of evaluation of the metropolis was created after the performance of analysis, preferring theoretically anchored approaches based on the three components, which are further commented on:

1. the population of the metropolis, a sufficient size of which is generally regarded as the initial assumption for starting the metropolisation process;

2. the economic profile emphasizing the progressivity of the economic structure evolving from the representation of knowledge-based industries;

3. the general attractiveness as a reflection of the high business and residential attractivity.

In the case of the population size, it should be mentioned that there is a lack of clear distinction between the metropolises and other major cities. The size limit of metropolises is influenced by a number of territorially differentiated factors, including the historical development and the achieved degree of urbanization. They can be seen, from the standpoint of administrative (administrative definition), as urban (continuously built-up areas) and functional (the influential territory of the city). Within this sequence, when the functional approach most corresponds with the metropolitan concept, an increase in the popula-tion of the respective units happens. In this context, a boundary of 1 million inhabitants is considered as a population limit, to be the size of supranationally significant metropolitan regions. $^{2}$ Metropolises of global importance occupy the highest hierarchical level (Friedmann, Wulff, 1976) - in this respect London and Paris are the most important global metropolises localized in Europe (Knox et al., 1995). In the case of metropolitan regions of secondary importance, the commonly used limit is a population of 500 thousand (Brezzi et al., 2012). During the evaluation, it is necessary to take into account the comparability of their territorial limits. Therefore, data provided by the OECD were selected as appropriate sources.

2 The so-called principal metropolises with an average of more than 1 million inhabitants consist of 52 cities in Europe (European Commission 2011). 
Table 1 | Factors of the Quality of the Business and Social Environment

\begin{tabular}{|c|c|}
\hline Quality of business environment & Quality of social environment \\
\hline business factors (B): & social factors (S): \\
\hline proximity to markets & life expectancy \\
\hline concentration of significant companies & education \\
\hline supporting services & unemployment \\
\hline presence of foreign companies & divorce rate \\
\hline Iabour factors (L): & abortion rate \\
\hline availability of labour forces & crime rate \\
\hline quality of labour forces & demographic factors $(D)$ : \\
\hline availability of labour forces & natural increase/decrease \\
\hline infrastructure factors $\left(I_{1}\right)$ : & migration \\
\hline road and railway quality & age index \\
\hline information and communication technology & urban factors $(U)$ : \\
\hline proximity to international airports & urbanization \\
\hline regional and local factors $(R / L)$ : & urban development \\
\hline entrepreneurial and knowledge base & urban environment (genius loci) \\
\hline assistance of public administration & infrastructure factors $\left(I_{2}\right)$ : \\
\hline price factors $(P)$ : & healthcare infrastructure \\
\hline price of labour & social infrastructure \\
\hline price of real estate & environmental factors $\left(E_{2}\right)$ : \\
\hline environmental factors $\left(E_{1}\right)$ : & landscape \\
\hline urban and natural attractiveness & air quality \\
\hline environmental quality & \\
\hline
\end{tabular}

Note: In the case of evaluation of the quality of social environment the weights of factors have not been determined.

Source: Viturka et al., 2010

The logic of the classification of the economic profile focussing on the representation of the knowledge-based sector is not significantly disputed, since these sectors are the primary premise of the intensive involvement of the metropolises in the global economy. A high degree of complexity provides a number of competitive advantages to the metropolis connected with lower transaction costs and synergistic effects of investments. These advantages support the exceptional position of metropolises as centres of production, exchange and consumption and also strengthen their coordination functions. Big cities logically have suitable conditions for diversification, and, thanks to access to knowledge, also to systematic specialization in sectors with high added value (OECD, 2006). Progressive 
industry groups taken from the study The Metropolization of the European Urban and Regional System (Krätke, 2006) were used in the basic assessment of the given component.

Evaluation of general attractiveness is the most complicated matter. On the other hand, its inclusion balances a certain partiality of both previous components. We consider the evaluation of the quality of the business and social environment (see Table 1) to be a suitable basis for a comprehensive approach. The elaborated method takes into account the results of international investigations, and its explanatory power has been verified through three applications carried out in the period 1997 to 2010 (Viturka, 2014). However, it is necessary to make use of the results of systemically similarly based research, due to the limitations of these applications only to the Czech Republic. In this regard, priority has been given to internationally respected European cities monitor from Cushman \& Wakefield based on the 12 stabilized groups of weighted factors, which generally correspond $(\rightarrow)$ with the factors listed in Table 1: access to markets and clients $(\rightarrow B)$, the availability of qualified $\operatorname{staff}(\rightarrow \mathrm{L})$, the quality of telecommunications and transport links $\left(\rightarrow \mathrm{I}_{1}\right)$, the supply of office space, the assistance of public administration $(\rightarrow \mathrm{R} / \mathrm{L})$, the price of office space and labour $(\rightarrow \mathrm{P})$ the environmental quality, the living conditions $\left(\rightarrow \mathrm{E}_{1}\right)$, language skills. Mercer's rankings are then used for the evaluation of the quality of the social environment. These are based on 10 groups of factors: the political and social environment, the sociocultural environment $(\rightarrow S, D)$ schools and education $(\rightarrow S, U)$, housing, public services, recreation $(\rightarrow U)$, health and sanitation $\left(\rightarrow I_{2}, E_{2}\right)$, the natural environment $\left(\rightarrow E_{2}\right)$, and consumer goods.

\section{Assessment of the Metropolitan Processes and the Synthesis of Results}

In this section, the results of the application of the created method on the example of the Cent-ral European metropolises are presented, with an emphasis on the description of the main and additional evaluation criteria (allowing the addressing of deficits in the availability of infor-mation). An emphasis is also laid on the explanatory power of the evaluation based on the previously described components, and on the synthesis of the obtained results through their typology. For a definition of the working macroregion of Central Europe, the publications the World Factbook, the Encyclopædia Britannica and Brockhaus Enzyklopädie were used as the main documents. On the basis of these definitions, Central Europe includes a total of nine countries: Germany, Poland, the Czech Republic, Hungary, Austria, Switzerland (together with Liechtenstein), Slovakia and Slovenia, with a sum of the current number of about 163 million inhabitants.

\subsection{The population size of the metropolis}

The above-mentioned size limit of a metropolis of supranational importance of one million inhabitants was, for practical reasons (or rather for the comparatively strong international position of a series of smaller metropolises), reduced to a population of 750 thousand. Two capital cities which do not meet even the reduced limit - Bratislava, with a population of around 722 thousand, and Ljubljana, with a population of about 576 thousand 
Table 2 | Data about the Population (2012) and GDP (2010) of Central European Metropolises

\begin{tabular}{|c|c|c|c|c|c|c|}
\hline Country/area & $\begin{array}{c}\text { Number } \\
\text { of inhabi- } \\
\text { tants }\end{array}$ & $\begin{array}{l}\text { Population } \\
\text { of the core }\end{array}$ & $\begin{array}{c}\text { Population } \\
\text { density } \\
\text { per km }{ }^{2}\end{array}$ & $\begin{array}{c}\text { GDP } \\
\text { in million } \\
\text { USD }\end{array}$ & $\begin{array}{l}\text { GDP in USD } \\
\text { per capita }\end{array}$ & $\begin{array}{c}\% \text { share } \\
\text { of total GDP }\end{array}$ \\
\hline Czech Republic & $10,505,445$ & - & 136 & 249,139 & 23,712 & - \\
\hline Prague & $1,868,631$ & $1,317,563$ & 476 & 76,017 & 41,543 & 30.5 \\
\hline Germany & $81,843,743$ & - & 229 & $2,741,802$ & 33,517 & - \\
\hline Berlin & $4,386,551$ & $3,475,702$ & 710 & 131,116 & 29,971 & 4.8 \\
\hline Rhein-Ruhr * & $7,089,648$ & $4,578,717$ & 1,171 & 258,707 & 36,366 & 9.4 \\
\hline Hamburg & $2,996,750$ & $1,718,809$ & 520 & 134,128 & 44,934 & 4.9 \\
\hline Munich & $2,904,480$ & $1,401,899$ & 464 & 146,077 & 51,350 & 5.3 \\
\hline Frankfurt/M. & $2,525,458$ & 885,001 & 650 & 122,873 & 48,802 & 4.5 \\
\hline Stuttgart & $1,960,286$ & 766,539 & 986 & 83,849 & 42,895 & 3.1 \\
\hline Mannheim & 801,951 & 584,698 & 1,195 & 45,297 & 36,501 & 1.7 \\
\hline Hannover & $1,220,106$ & 508,444 & 395 & 44,420 & 36,327 & 1.6 \\
\hline Nuremberg & $1,168,145$ & 608,517 & 374 & 44,985 & 38,548 & 1.6 \\
\hline Bremen & $1,026,367$ & 545,080 & 323 & 37,363 & 36,431 & 1.4 \\
\hline Leipzig & 833,828 & 512,479 & 393 & 21,708 & 25,917 & 0.8 \\
\hline Dresden & 842,159 & 527,089 & 491 & 21,246 & 25,383 & 0.8 \\
\hline Poland & $38,538,447$ & - & 123 & 662,316 & 17,353 & - \\
\hline Warsaw & $3,008,921$ & $1,714,967$ & 349 & 111,665 & 37,456 & 16.9 \\
\hline Katowice ${ }^{* *}$ & $2,608,651$ & $1,470,265$ & 665 & 52,878 & 20,119 & 8.0 \\
\hline Krakow & $1,357,206$ & 753,647 & 362 & 26,652 & 19,716 & 4.0 \\
\hline Gdansk & $1,098,435$ & 702,372 & 420 & 22,350 & 20,470 & 3.4 \\
\hline Lodz & 947,767 & 794,938 & 560 & 18,781 & 19,642 & 2.8 \\
\hline Poznan & 941,914 & 552,546 & 306 & 25,899 & 27,729 & 3.9 \\
\hline Wroclaw & 835,403 & 630,127 & 317 & 19,734 & 23,691 & 3.0 \\
\hline Switzerland & $7,954,662$ & - & 199 & 306,377 & 39,351 & - \\
\hline Zürich & $1,226,332$ & 369,768 & 1,043 & 58,058 & 48,128 & 19.0 \\
\hline Geneva & 807,646 & 270,323 & 516 & 31,432 & 40,039 & 10.3 \\
\hline Basel & 773,332 & 166,097 & 541 & 29,618 & 38,635 & 9.7 \\
\hline Austria & $8,443,018$ & - & 102 & 296,484 & 35,400 & - \\
\hline Vienna & $2,737,753$ & $1,750,472$ & 301 & 107,616 & 40,107 & 36.3 \\
\hline Hungary & $9,957,731$ & - & 107 & 169,811 & 16,957 & - \\
\hline Budapest & $2,862,326$ & $1,705,774$ & 473 & 80,888 & 28,417 & 47.6 \\
\hline Slovakia & $5,404,322$ & - & 110 & 109,463 & 20,178 & - \\
\hline Bratislava & 722,106 & 431,418 & 278 & 32,492 & 45,414 & 29.7 \\
\hline Slovenia & $2,055,496$ & - & 102 & 51,416 & 25,118 & - \\
\hline Ljubljana & 576,370 & 278,705 & 183 & 19,775 & 34,870 & 38.5 \\
\hline
\end{tabular}

Note: * According to the OECD the aggregate population of the metropolitan region consists of Düsseldorf, Köln am Rhein, Dortmund, Duisburg, Essen, Bonn and Bochum. But the comprehensively defined polycentric metropolitan region of Rhein-Ruhr has a population of almost 10 million (the data from Staatskanzlei des Landes Nordrhein-Westfalen: LEP NRW).

** The figure for the polycentric metropolitan region Górnośląski (Katowice, Sosnowiec and other cities). Source: OECD, 2015 
(OECD, 2015), were also included. ${ }^{3}$ A total of 27 metropolises or metropolitan regions were identified: 12 of them are located in Germany, seven in Poland and three in Switzerland (its excellent position demonstrates the extraordinary level of global integration of its economy). Considerable attention was paid to the solution of questions of the definition of large polycentric metropolitan regions. At this point, it is also appropriate to highlight the problem of the comparability of statistical data in the metropolitan areas of post-socialist Central Europe related to the census data versus the annual population register. For example, Steinführer et al. (2010) found the significant statistical variations in the measurements of the population size (influenced by suburbanization, intraregional and international labour out-migration, etc.) However, these impacts are negligible in terms of the results of our research. Specific data about metropolitan areas are based on the uniform method for defining functional urban areas introduced by the OECD in collaboration with the EU. Here, it is appropriate to mention some fundamental features (Brezzi et al., 2012):

- the basic building blocks of regionalization are units at LAU 2 level;

- the core of the region is determined on the basis of the minimum population size of a continuously urbanized area;

- $\quad$ in the case of nearby cores, their mutual relations are tested on the basis of commuting time, due to the identification of the polycentric structure;

- the hinterland of the core consists of the municipalities from which at least $15 \%$ of workers commute to work.

Selected metropolises can be in accordance with their basic demographic importance divided into three size groups: metropolises with a population of more than 2.5 million, metropolises with a population of 1 to 2.5 million and metropolises with a population of less than 1 million. The highest average growth rate of GDP in comparison with the corresponding national growth rates was found in the first size group including nine metropolises. This fact suggests a tendency to strengthen the position of the largest metropolises.

\subsection{Economic profile of the metropolis}

A progressive economic profile with a rapidly growing share of knowledge-based high-tech sectors in industry and services is widely regarded as the typical character of a metropolis. Services, in which the research of knowledge economy is sometimes significantly concentrated, generally grow more than industry and are also more resilient to cyclical crises. Metropolitan regions are the centres for knowledge-based production chains and innovationstrong production clusters (Krätke, 2006). The concentration of the corresponding global firms has been analysed at Loughborough University (GaWC, 2014). Unfortunately, this database

3 The specified size limit is only met by Prague out of the Czech metropolitan regions. Among the other metropolitan regions, this limit is significantly closer in Brno and Ostrava, which are further analysed in Section 4. The regions of the remaining Czech regional cities do not satisfy this condition and their occasional inclusion in the metropolis is not sufficiently verified and is more likely marketing significance - the updated version of the Spatial Development Policy of the Czech Republic corresponds with it (MMR, Institute for Spatial Development, 2015). 
often has gaps for single EU regions, as well as for certain periods of time. In accordance with the available knowledge, the metropolises can be grouped into the following groups:

1. Group A: above average proportion of HTI (research-intensive high technolocgy industrial branches) + MTI (research-intensive medium high technology industrial branches) + TS (knowledge-intensive technology-related services);

2. Group B: above average proportion of ES (knowledge-intensive market-related enterprise services) + FS (knowledge-intensive financial services) + HEM (knowledgeintensive services in healthcare, education and the media industry);

3. Group $\mathrm{C}$ : average proportion of knowledge-based industries with a better position of technology-related branches (HTI + MTI + TS);

4. Group D: average proportion of knowledge-based industries with a better position of service-related branches (ES + FS + HEM);

5. Group E: below average proportion of research-intensive and knowledge-intensive branches.

Table 3 | Economic Profile of the Central European Metropolises

\begin{tabular}{|l|l|l|l|l|}
\hline \multicolumn{1}{|c|}{ Group A } & \multicolumn{1}{c|}{ Group B } & \multicolumn{1}{c|}{ Group C } & \multicolumn{1}{c|}{ Group D } & \multicolumn{1}{c|}{ Group E } \\
\hline Stuttgart & Hamburg & Dresden & Prague & Katowice \\
\hline Mannheim & Munich & & Berlin & Krakow \\
\hline Hannover & Frankfurt/M. & & Rhein-Ruhr & Gdansk \\
\hline Nuremberg & Zürich & & Bremen & Lodz \\
\hline Basel & Geneva & & Leipzig & Poznan \\
\hline & & & Warsaw & Wroclaw \\
\hline & & & Vienna & \\
\hline & & & Budapest & \\
\hline & & & Bratislava & \\
\hline & & & Ljubljana & \\
\hline
\end{tabular}

Source: Eurostat, own research

The Eurostat Regio database was selected to assess the economic profile due to the need to have comprehensive data based on territorial structure (the most recent data are available for 2011). It would be optimal to have the data at a NUTS 3 regional level for a regionally conceived rendering of the economic profile of the metropolis. However, most of the Eurostat data is available only up to NUTS 2 level, and it is necessary to take this fact into account. In accordance with this, the final evaluation works only with three classification groups of metropolises, when metropolises of profile groups A and B are sorted into above-average, metropolises of profile groups $\mathrm{C}$ and $\mathrm{D}$ into average, and metropolises of profile group E into a below-average group. The data about employment in selected sectors of industry entered their own structural analysis, registered at level NUTS 2, and further data about employment in selected services are registered at level NUTS 3 (with 
the exception of the communication and information activities TS, where it was necessary to use level NUTS 2 due to the lack of data for German regions - this level corresponds with their assignment to the industry and the sectoral groups A and B, respectively). Employment, according to the examined sectoral groups, was compared to total regional employment and the shares found were used for the classification of the individual metropolises within the basic groups.

The highest number of metropolises fall within the above-average and the average groups (the three wealthiest metropolises belong to group B), then only Polish metropolises, with the exception of Warsaw, fall into the below-average group. The final classification of some metropolises requires the additional analyses. These were particularly Ljubljana (incomplete data) and Basel (a significant difference in the size of statistical and functional regions).

\subsection{Attractiveness of metropolises}

The quality of the business environment or business attractiveness (BA) occupies a central position in the case of the evaluation of metropolises' attractiveness. Information from the European Cities Monitor/ECM presenting the views of approximately 500 respondents from a range of managers of the world's leading companies (Cushman \& Wakefield, 2011) was used for its evaluation. Within the framework of the Central European macroregion, at the beginning of the current decade rankings included a total of 13 cities, whose semantic position was assessed primarily on the basis of data for 1990, 2000 and 2010. Due to the lack of geographic coverage of the whole examined macroregion, this information was accompanied by time-corresponding data obtained from the benchmarking of large cities created by the HWWI/Berenberg bank, with an emphasis on the results of the aggregate rating of location advantages (Neumann, 2013) and further from the database of GaWC, Loughborough University. ${ }^{4}$ The researched metropolises can be, on the basis of BA, divided from a broader perspective into three basic categories:

1. metropolises of global importance - five metropolises;

2. metropolises of European importance - seven metropolises;

3. metropolises of Central European importance - fifteen metropolises (ECM database includes only Bratislava).

The overall ranking of the metropolises for the first two categories was set out in order to increase the explanatory value of the information. In the case of the third category, only the domestic order of the German and Polish metropolises was set out. To achieve higher complexity, the results of the evaluation by the BA of the metropolises were compared with their position in terms of the evaluation of the social environment quality or residential attractiveness (RA), and also in terms of their innovation potential (IP). Data from Mercer,

$4 \quad$ The results of the evaluation were confronted with the indicator of GDP per capita obtained from the database of the OECD and other information (the worst availability of relevant information was encountered in the case of the smallest metropolises) because of only partial compliance with the structure of these data. 
Table 4 | Attractiveness of Central European Metropolises

\begin{tabular}{|c|c|c|c|c|c|}
\hline & $\begin{array}{c}\text { Order by BA } \\
\text { - total/ } \\
\text { within the } \\
\text { countries }\end{array}$ & $\begin{array}{l}\text { Variations } \\
\text { in the order } \\
\text { according } \\
\text { to RA }\end{array}$ & $\begin{array}{l}\text { Variations } \\
\text { in the order } \\
\text { according } \\
\text { to IP }\end{array}$ & $\begin{array}{l}\text { Growth of the } \\
\text { inhabitants } \\
\text { of metrop./state } \\
(2000-2011)\end{array}$ & $\begin{array}{c}\text { Growth } \\
\text { of the GDP } \\
\text { of metrop./ } \\
\text { state (2000- } \\
2011)\end{array}$ \\
\hline \multicolumn{6}{|l|}{ 1. Category } \\
\hline Berlin & 2 & $\nabla$ & $\bullet$ & 101,7 & 103,6 \\
\hline Rhein-Ruhr & 5 & $\bullet$ & $\nabla$ & 98,2 & $104,2^{1}$ \\
\hline Munich & 3 & $\bullet$ & $\bullet$ & 113,5 & 100,7 \\
\hline Frankfurt/M. & 1 & $\nabla$ & $\nabla$ & 102,1 & 102,9 \\
\hline Zürich & 4 & $\Delta$ & $\nabla$ & 99,1 & $97,9^{2}$ \\
\hline \multicolumn{6}{|l|}{ 2. Category } \\
\hline Prague & 8 & $\nabla$ & $\bullet$ & 109,6 & 111,8 \\
\hline Hamburg & 7 & $\bullet$ & $\bullet$ & 102,7 & 102,2 \\
\hline Stuttgart & 11 & $\Delta$ & $\Delta$ & 102,0 & 101,9 \\
\hline Warsaw & 10 & $\nabla$ & $\nabla$ & 104,5 & 109,5 \\
\hline Geneva & 6 & $\bullet$ & $\nabla$ & 105,5 & $99,7^{2}$ \\
\hline Vienna & 9 & $\Delta$ & $\Delta$ & 106,8 & 99,6 \\
\hline Budapest & 12 & $\nabla$ & $\bullet$ & 105,5 & 112,2 \\
\hline \multicolumn{6}{|l|}{ 3. Category } \\
\hline Mannheim & 1 & $\nabla$ & $\nabla$ & 97,7 & 99,8 \\
\hline Hannover & 2 & $\bullet$ & $\bullet$ & 99,0 & 100,8 \\
\hline Nuremberg & 4 & $\Delta$ & $\bullet$ & 100,9 & 94,8 \\
\hline Bremen & 3 & $\bullet$ & $\nabla$ & 100,8 & 98,4 \\
\hline Leipzig & 6 & $\bullet$ & $\Delta$ & 97,2 & 104,2 \\
\hline Dresden & 5 & $\bullet$ & $\Delta$ & 103,7 & $99,0^{2}$ \\
\hline Katowice & 4 & $\bullet$ & $\bullet$ & 94,9 & 96,1 \\
\hline Krakow & 3 & $\Delta$ & $\bullet$ & 101,5 & 101,5 \\
\hline Gdansk & 5 & $\bullet$ & $\Delta$ & 102,4 & 97,0 \\
\hline Lodz & 6 & $\Delta$ & $\bullet$ & 94,0 & 98,5 \\
\hline Poznan & 1 & $\bullet$ & $\nabla$ & 103,4 & 98,1 \\
\hline Wroclaw & 2 & $\nabla$ & $\nabla$ & 100,8 & 104,5 \\
\hline Basel & $x$ & $\Delta$ & $\nabla$ & 94,7 & $99,5^{2}$ \\
\hline Bratislava & $x$ & $\bullet$ & $\bullet$ & 104,9 & 111,7 \\
\hline Ljubljana & $x$ & $\nabla$ & $\Delta$ & 106,4 & 107,6 \\
\hline
\end{tabular}

Note: 1 - without Köln am Rhein

2 - period 2008-2010

Source: Cushman \& Wakefield (2011), Mercer (2012), Innovation Cities (2015) 
managing the most well-known world database, specifically the average order for freely available surveys of 2011 and 2012 (Mercer, 2012), were used in the first case. The position of a metropolis is rated as balanced in the case of differences compared to the position according to the $\mathrm{BA}+/-1$ to 2 places $(\bullet)$. Above this level it is an unbalanced position with positive $(\boldsymbol{\Delta})$ or $(\boldsymbol{\nabla})$ negative deviations. Due to the fact that the collected information does not cover all the metropolises, additional resources had to be used once again. In this case, the information is taken from the webpage Numbeo quality of life by city for 2011 and 2014; it was necessary, in the case of Poland, to complete it with information from the database of GaWC (Bańczyk, 2012). The comprehensively conceived information, taken from world ranking processed by the 2thinkknow Consulting Agency since 2007, was used as a basic source of information about the IP. A quite extensive set of used indicators is aggregated here into three factors identified as cultural assets, human infrastructure and networked markets the average order for 2011 and 2014. In justified cases, this information has been accompanied by other resources (mainly Annoni, Dijkstra, 2013). The same procedure as for RA was used for a positional comparison with BA data.

\subsection{Comprehensive assessment}

The typology method, which sorts examined phenomena according to the similarity of the selected characteristics, was chosen due to the problems with the comparability of the data for the evaluation of the semantic position of the metropolises. In our case, we dealt with the degree of similarity in the classification of metropolises into groups within individual components - population size, economic profile and attractiveness (here expressed, due to the circumstances, only in the reduced form by using its main part, i.e. business attractiveness). ${ }^{5}$ The metropolises were classified into dominant, established and elementary types.

The statistical analysis of the results shows that the type classification of the metropolises has the strongest link to the component "attractiveness", with the correlation coefficient on a significance level of $0.05 \mathrm{k}=0.85$. We encounter a similar orientation of the priority links also for both remaining components, of which the more powerful dependency shows the component "size". If we extend the statistical analysis about the indicator of GDP per capita, we find the strongest link to the component "structure" with $\mathrm{k}=0.73$, which corresponds with the general premise about the higher added value of the production of knowledge-based industry. In addition to this, it is useful to note that we encounter above-average levels of this component only for the dominant and established metropolises. It can be stated that the findings documented the good explanatory power of the applied system of evaluation of the position of metropolises. In terms of the processes of development differentiation, the results showed a significantly better position of "Western" metropolises with a three-time weaker representation for the least developed elementary types of metropolises in comparison with the "Eastern" metropolises. If we focus on the components of evaluation, the significantly higher progressivity of economic structure corresponding to the higher level of their economic development speaks in favour

5 The choice of a narrower concept is a response to the danger of a loss of explanatory values while using the aggregation of indicators BA, RA and IP, whose links are not unequivocal. 
Table 5 | Comprehensive Overview of the Results of the Evaluation

\begin{tabular}{|c|c|c|c|c|}
\hline \multirow{2}{*}{$\begin{array}{l}\text { Metropolitan } \\
\text { types }\end{array}$} & \multicolumn{3}{|c|}{ Classification group } & \multirow{2}{*}{$\begin{array}{c}\text { Aggregate } \\
\text { group }\end{array}$} \\
\hline & size * & structure & attractiveness & \\
\hline \multicolumn{5}{|l|}{ A - dominant } \\
\hline Munich & 1 & 1 & 1 & I \\
\hline Frankfurt/M. & 1 & 1 & 1 & I \\
\hline Berlin & 1 & 2 & 1 & I \\
\hline Rhein-Ruhr & 1 & 2 & 1 & I \\
\hline Zürich & 2 & 1 & 1 & I \\
\hline Hamburg & 1 & 1 & 2 & I \\
\hline \multicolumn{5}{|l|}{ B - established } \\
\hline Vienna & 1 & 2 & 2 & II \\
\hline Warsaw & 1 & 2 & 2 & II \\
\hline Budapest & 1 & 2 & 2 & II \\
\hline Stuttgart & 2 & 1 & 2 & II \\
\hline Prague & 2 & 2 & 2 & II \\
\hline Geneva & 3 & 1 & 2 & II \\
\hline Nuremberg & 2 & 1 & 3 & II \\
\hline Hannover & 2 & 1 & 3 & II \\
\hline Basel & 3 & 1 & 3 & II \\
\hline Mannheim & 3 & 1 & 3 & II \\
\hline Katowice & 1 & 3 & 3 & II \\
\hline \multicolumn{5}{|l|}{ C-elementary } \\
\hline Bremen & 2 & 2 & 3 & III \\
\hline Bratislava & 3 & 2 & 3 & III \\
\hline Ljubljana & 3 & 2 & 3 & III \\
\hline Leipzig & 3 & 2 & 3 & III \\
\hline Dresden & 3 & 2 & 3 & III \\
\hline Gdansk & 2 & 3 & 3 & III \\
\hline Krakow & 2 & 3 & 3 & III \\
\hline Poznan & 3 & 3 & 3 & III \\
\hline Wroclaw & 3 & 3 & 3 & III \\
\hline Lodz & 3 & 3 & 3 & III \\
\hline
\end{tabular}

Note: * 1 - more than 2.5 mil. inhabitants

$2-1$ to 2.5 mil. inhabitants

3 - less than 1 mil. inhabitants

The order of the metropolises with the same number of points was determined using the criteria of political positions and GDP per capita.

Source: own research. 
of Western metropolises. Substantially smaller differences found for the components of BA, crucial from the standpoint of future competitiveness, can be primarily attributed to the lower price level of essential factors of production in the Eastern metropolises. The price of labour and land is ranked among the important localization factors representing a stimulus of economic cooperation. In the case of metropolises, such cooperation is implemented, especially by using optimization of vertical linkages in the upper floors of the production networks of transnational companies. The intensity of mutual business interactions, which is strongest in Slovakia, Hungary and Austria, indicates the relevant demand for cooperation in the given macroregion.

\section{Conceptualizing the Metropolisation Processes in the Example of the Czech Republic}

The results of the evaluation of metropolises form a basic framework for the strategically targeted conceptualization. In the presented example, we mainly focus on the assessment of the intensity of the links between Prague, accompanied by two following important centres Brno and Ostrava (the functional regions of Brno and Ostrava reached the population size of 643 and 563 thousand in 2012; OECD 2015), and other Central European metropolises and perceptions of their development potential. The procedure consists of the following steps:

- evaluation of the intensity of ties with an emphasis on the identification of development axes of supranational importance;

- $\quad$ synthesis of obtained knowledge in the context of a spatial model of the development of the Czech economy;

- the final conceptualization of the research results with the use of scenarios of regional development (level NUTS 3).

The evaluation of metropolitan links is based on a gravity model as a standard tool of a qualified estimate of potential interactions:

$$
G_{i j}=\frac{M_{i} \times M_{j}}{d_{i j}},
$$

where $G_{i j}=$ the gravity force acting between the metropolises $i$ and $j$,

$M_{i}, M_{j}=$ the economic importance of metropolises,

$d_{i j}=$ the distance of metropolises.

For measuring the importance, GDP created in metropolitan regions in 2010 was used, and the distance of the metropolis corresponds to the length of the fastest road connection. ${ }^{6}$ The model shows the strongest links of Prague to Berlin and Munich with a value of $\mathrm{G}=29$ and also to Vienna with $G=25$. From a broader perspective, the metropolitan axis PragueNuremberg-Munich seems to be the most important, with the aggregate value $\mathrm{G}$ given by the sum of $\mathrm{P} \leftrightarrow \mathrm{N}$ and $\mathrm{P} \leftrightarrow \mathrm{M}=41$, followed by the axis of the Prague-Dresden-Berlin with $\mathrm{G}=40$. The importance of these axes shows the current shares of the German federal land

6 During the evaluation, metropolises were preferred that met the criterion of the so-called effective distance, that is, in the case of road freight transport as the most important means of transport of goods, in accordance with the relevant EU legislation (regulation of the daily working time of drivers) set at $600 \mathrm{~km}$. 
concerned with the foreign trade of the Czech Republic with Germany - turnover/import: Bayern 23/29\%, Baden-Württemberg 16/20\%, Nordrhein-Westfalen 15/14\%, Sachsen 7/9\% and Hessen 6/6\% (The Federal Statistical Office 2012). Brno has the strongest ties to Vienna and Ostrava to Katowice $(\mathrm{G}=11$ or 7$)$. From a broader perspective the metropolitan axis PragueBrno-Vienna (from which a metropolitan axis diverges pointing over Bratislava to Budapest) plays decisive role. Spatial coherence of the development axes of supranational and national importance then enhances horizontal integration. In this direction, the metropolitan axis Prague-Munich with the West Bohemia axis Prague-Pilsen, the metropolitan axis PragueBerlin with the North Bohemia axis Prague-Ústí n. L. and the metropolitan axis PragueVienna with the Bohemia-Moravia axis Prague-Jihlava-Brno show strong interactions; Ostrava is actually not connected to the national system of defined developing axes.

At the start of the second step, it should be mentioned that the created spatial model of the economic development of the Czech Republic, whose basis is the structured network of precisely defined development poles and axis), clearly illustrates the determinative role of Prague (Viturka et al., 2010; Ženka, Čadil, 2009). Its administratively defined region shows the best quality of the business environment/QBE within the framework of 13 regional capitals including Prague, attaining a value of 1.16 under the applied five-level classification system. Prague also occupies fourth position in the case of the quality of the social environment/ QSE. This strategically important fact confirms the creation of six axes of national importance. ${ }^{7}$ Complicated situation in the eastern part of the republic reflects the ongoing reorganization of the socio-geographical arrangement of the Moravian area, particularly the decline of traditional industry in the Ostrava agglomeration and the development of new industries in the Brno agglomeration. Brno with its levels of QBE ranks right behind Prague; Ostrava, on the other hand, takes fourth place from the end (in the case of QSE, Brno and Ostrava took the eighth respectively last position). Only Brno thus can be given the position of a secondary metropolis of supranational importance corresponding to wider importance of its activities, in particular, in R\&D and international exhibitions (Viturka, 2015).

The main focus of the third step is the application of the scenarios method with the right mix of priorities. In accordance with the evaluation of QBE, QSE and the SWOT analysis (Viturka et al., 2010) this seems for Prague like the optimal application of progressive scenario giving preference to the quality of development. From its priorities, the improvement of the quality of life, $R \& D$ and the institutional environment are crucial. The main objective is to improve the international position of Prague as an attractive place to live and for the localization of companies' headquarters and creation of conditions for cooperation with foreign metropolises (with the emphasis on the dissemination of knowhow and urban vision), especially with Munich, Berlin and Vienna. In accordance with the results of the analyses carried out, the growth scenario looks the best for Brno and the adaptation scenario for Ostrava. Strengthening the position of Brno requires a "smart" strategy, the priorities of which we consider to be increasing the innovation potential and the development of business and R\&D clusters in interaction with the improvement of the QSE. The economic development of the Ostrava has been influenced by the strong representation of economically sensitive industries and the lower representation of higher

7 The axes connect development poles consisting of regional centres with an above-average QBE, while intermediate microregions have positive deviations of QBE from the theoretical values corresponding to their population size. 


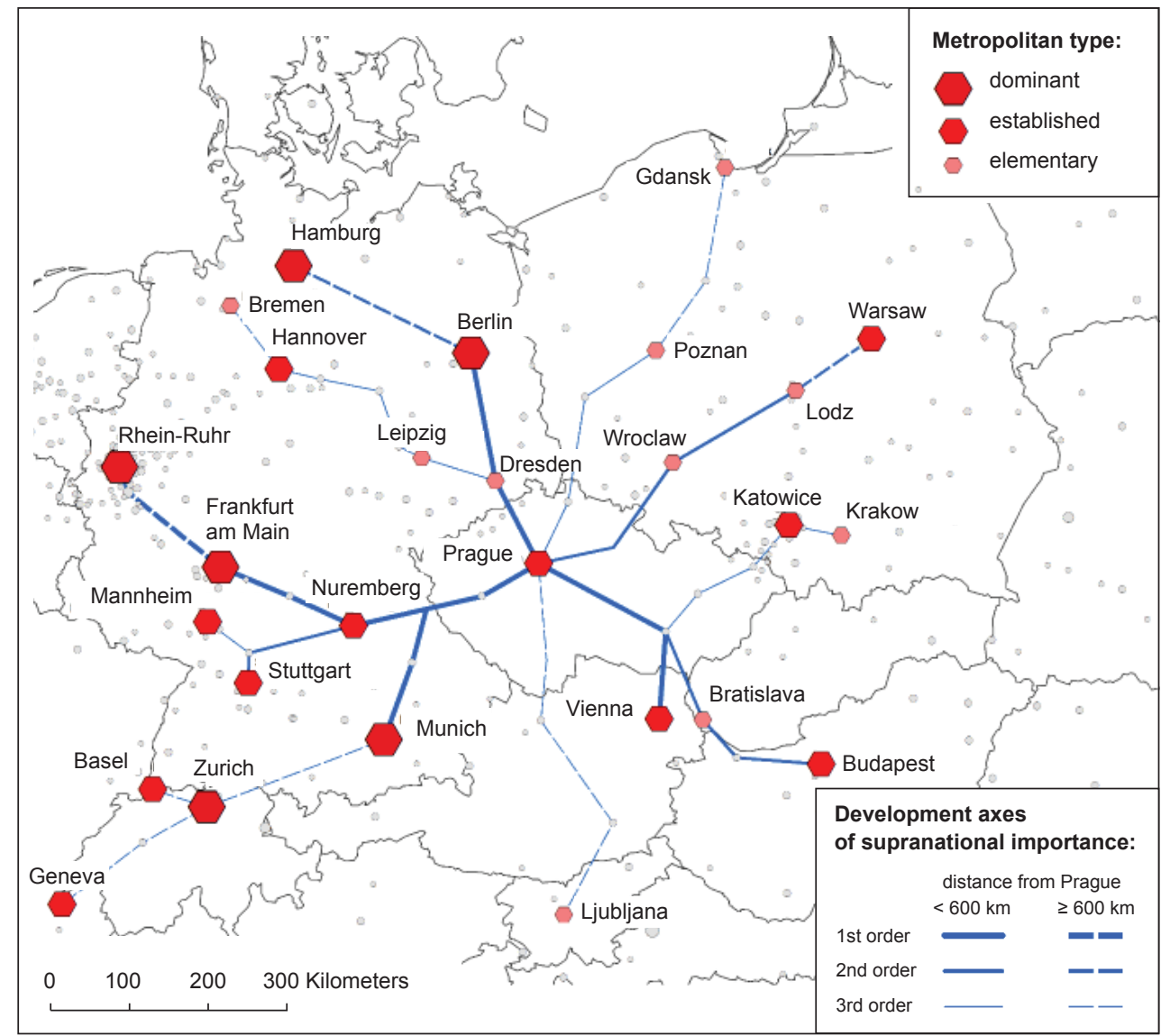

Source: own research

market services. An improvement of the QBE and QSE with positive effects on the total attractiveness, were determined as the main priorities of the scenario. Overall, we consider as a fundamental constitution (currently deprived) the Central Moravian axis BrnoOlomouc-Ostrava to be an integral component of the Baltic-Adriatic axis Gdansk-WarsawBrno-Vienna-Graz-Venice-Ravenna.

\section{Conclusion}

Evaluation of the metropolis is an important basis for the creation of supranational development concepts, with an emphasis on the metropolitan networks as one of the building blocks of territorial integration (this was taken into account also in the strategic document Europe 2020). Its foundation should be a thorough analysis based on theoretically anchored and practically proven methods. In this context, the presented analysis of three components covering the main determinants of the development - the input assumptions 
(population size), the ability of adaptation (economic profile) and development potential (attractiveness), can be regarded as an inspirational approach. Prerequisites for the successful application are the comprehensiveness and quality of the input data that guarantees the real benefits on the knowledge of the current state of the metropolisation process, which can be deepened through generalisation and practically targeted conceptualisation of the results. The suggested approach was demonstrated on the example of the Czech Republic using the typology of metropolises as the basic design of a long term strategy of their development. From a broader perspective, it is necessary to note that cooperation of metropolises is influenced by a number of other factors (in this context, we point out the interesting issue of the "Central European rooting" of the countries). In this context, the German metropolises Berlin, Munich and Frankfurt/M. together with the Austrian metropolis Vienna have a crucial importance from the perspective of the Czech metropolises Prague followed by Brno. The strengthening of the mutual economic and social ties can be considered a key condition for improving the international position of our metropolises. The long-term and systemic coordination of the development of the metropolitan areas significantly contributes to the socioeconomic development by preventing inconsistency in the actions of the stakeholders. In the actual EU programming period 2014-2020 a new tool of integrated territorial investments (ITI) aimed at the support of cities and urban areas was approved in the partnership agreement between the European Commission and the Czech Republic. The successful implementation of the above mentioned basic priorities of both Czech metropolises then depends on the political consensus on their specific form. For example, in the case of Brno, ITI includes four key areas - smart mobility, environment, competitiveness and education, social and health (statutory city of Brno, 2015). The European Commission thus gave an indirect motivation to deeper spatial metropolitan analyses and started a process of the gradual institutionalization of the metropolitan areas.

\section{References}

Abrantes, P., Bação, F., Lobio, V., Tenedório, J. (2005). Spatial Modelling of Metropolisation in Portugal. 14th European Colloquium on Theoretical and Quantitative Geography. Tamar, Portugal, 1-18. Available at: http://www.novaims.unl.pt/labnt/ geosom/Public/o4-Spatial\%20modelling\%20.pdf

Annoni, P., Dijkstra, L. (2013). EU Regional Competitiveness Index. Joint Research Centre, Scientific and Policy Report, European Commission, https://doi.org/10.2788/61698

Bańczyk, M. (2012). From Connectivity to Metropolis Power: Measuring National City Networks with METROX Methodology - The Case Of Poland. Globalization and World Cities Research Bulletin, 341. Available at: http://www.lboro.ac.uk/gawc/rb/rb341.html

Brezzi, M., Piacentini, M., Rosina, K, Sanchez-Serra, D. (2012). Redefining Urban Areas in OECD Countries. Redefining Urban: A New Way to Measure Metropolitan Areas. Paris: Organization for Economic Cooperation and Development, 19-58, https://doi. org/10.1787/9789264174108-en

Bourdeau-Lepage, L. (2004). Metropolization in Central \& Eastern European: Unequal Chance. Globalization and World Cities Research Bulletin, $141(\mathrm{~A})$. Available at: http://www.lboro. ac.uk/gawc/rb/rb141.html

Brender, N., Golden, A. (2007). Mission Impossible: Successful Canadian Cities. Paper presented at The Conference Board of Canada III. Ottawa, Canada. 
Cushman \& Wakefield (2011). European Cities Monitor. New York: Cushman \& Wakefield.

Duranton G. (1999). Distance, Land, and Proximity: Economic Analysis and the Evolution of Cities. Research Papers in Environmental and Spatial Analyses, 31(12), 2169-2188, https://doi.org/10.1068/a312169

European Commission (2011). Cities of Tomorrow - Challenges, Visions, Ways Forward. Luxembourg: Publication Office of the European Union, https://doi.org/10.2776/41803

European Environment Agency (2006). Urban Sprawl in Europe: The Ignored Challenge. Luxembourg: Office for Official Publications of the European Communities, https://doi. org/10.1155/2014/690872

Frantál, B., Greer-Wotten, B., Klusáček, P., Kunc, J., Martinát, S. (2015). Exploring Spatial Patterns of Urban Brownfields Regeneration: The Case of Brno, Czech Republic. Cities, 44, 9-18, https://doi.org/10.1016/j.cities.2014.12.007

Friedman, J., Wulff, R. (1976). Urban Transition: Comparative Studies of New Industrializing Societies. London: Hodder \& Stoughton Educational, https://doi. org/10.1177/009614428000600301

GaWC (2014). Globalization and World Cities. Loughborough: Loughborough University, Study Group and Network, https://doi.org/10.1111/jors.12109

Growe, A. (2012). Emerging Polycentric City-Regions in Germany. Regionalisation of Economic Activities in Metropolitan Regions. Erdkunde, 66(4), 295-311, https://doi.org/10.3112/ erdkunde.2012.04.02

Hampl, M. (1996). Geografická organizace společnosti a transformační procesy v České republice (Geographical Organization of Society and Transformation Processes in the Czech Republic). Prague: Charles University.

Hanssens, H., Derudder, B., Witlox, F. (2012). Managing Organizational and Geographical Complexity: The Positionality of Advanced Producer Services in the Globalizing Economies of Metropolitan Regions. Erdkunde, 66(1), 45-55, https://doi.org/10.3112/ erdkunde.2012.01.04

Ianoş, I., Peptenatu, D., Drăghcii, C., Pintilii, R., D. (2012). Management Elements of the Emergent Metropolitan Areas in a Transition Country. Romania as a Case Study. Journal of Urban and Regional Analysis, 4(2), 149-171, https://doi. org/10.1177/09697764030104002

Innovation Cities (2015). 2thinkknow Innovation Cities. Melbourne: 2THINKNOW

Knox, P. L., Taylor, P. J. (Eds.). (1995). World Cities in a World-System. Cambridge: Cambridge University Press.

Kraft, S., Halás, M., Vančura, M. (2014). The Delimitation of Urban Hinterlands Based on Transport Flows: A Case Study of Regional Capitals in the Czech Republic. Moravian Geographical Reports, 22(1), 24-32, https://doi.org/10.2478/mgr-2014-0003

Krätke, S. (2006). The Metropolization of the European Urban and Regional System. Globalization and World Cities Research Bulletin, 193, https://doi. org/10.1080/09654310601016424

McCann, P. (2010). Urban and Regional Economics. Oxford: Oxford University Press.

Mercer (2012). Quality of Living Worldwide City Rankings Survey. Warsaw: Marsh \& McLennan Companies, Mercer.

MMR, ÚÚR (2015). Politika územního rozvoje České republiky ve znění aktualizace č. 1. (Spatial Development Policy of the Czech Republic in the Wording of the Update No. 1). Prague: Ministry of Regional Development. 
Neumann, U. (2013). City Ranking - A Useful Instrument for Regional Analysis and Policy? Paper presented at the Acatech CAE Workshop "A Ranking Scheme for Intelligent Cities", Munich, Deutsche akademie der Technikwissenschaften.

OECD (2006). Competitive Cities in the Global Economy. Paris: Organization for Economic Cooperation and Development. Territorial Reviews, https://doi. org/10.1787/9789264027091-en

OECD (2015). Metropolitan Areas. Paris: Organization for Economic Cooperation and Development. Statistics.

Sassen, S. (1991). The Global City. Princeton: Princeton University Press.

Statutory city of Brno (2015). Atlas brněnské metropolitní oblasti. (Atlas of Brno Metropolitan Area). Available at: https://www.brno.cz/fileadmin/user_upload/sprava_mesta/Strategiepro_Brno/dokumenty/iti/final_Atlas-BMO-complet-preview.pdf

Steinführer, A., Bierzyński, A., Großmann, K, Haase, A., Kabisch, S., Klusáček. P. (2010). Population Decline in Polish and Czech Cities during Post-socialism? Looking Behind the Official Statistics. Urban Studies, 47(11), 2325-2346.

The Federal Statistical Office (2012). Vorläufige Ergebnisse (Preliminary results). Wiesbaden: Das Statistische Bundesamt.

Viturka, M., Halámek, P., Klímová, V., Tonev, P., Žítek, V. (2010). Kvalita podnikatelského prostředí, regionální konkurenceschopnost a strategie regionálního rozvoje České republiky. (The Quality of the Business Environment, Regional Competitiveness and Regional Development Strategy of the Czech Republic). Prague: Grada.

Viturka, M. (2014). Integrative Model for Evaluation of Development Potentials of Regions and Its Application on an Example of the Czech Republic. Economics and management, 17(4), 4-19, https://doi.org/10.15240/tul/001/2014-4-001

Viturka, M. (2015). Monocentrický scénář perspektivního uspořádání moravského prostoru - realistická či fiktivní představa (Monocentric Scenario of Perspective Arrangement of Moravian Space - Realistic or Fictious Idea?). XVIII. International Colloquium on Regional Sciences, 217-222, ttps://doi.org/10.5817/CZ.MUNI.P210-7861-2015-29

Ženka, J., Čadil, V. (2009). Regional Distribution of Technology-Intensive Manufacturing Industries in the Czech Republic with an Accent on Risk of Delocalisation. Prague Economic Papers, 19(1), 61-77, https://doi.org/10.18267/j.pep.342 